A Tale of Two Mayors: Courts and Politics in Iran and Turkey

Author(s): Hootan Shambayati

Source: International Journal of Middle East Studies, Vol. 36, No. 2 (May, 2004), pp. 253275

Published by: Cambridge University Press

Stable URL: https://www.jstor.org/stable/3880034

Accessed: 29-12-2018 16:35 UTC

\title{
REFERENCES
}

Linked references are available on JSTOR for this article:

https://www.jstor.org/stable/3880034?seq=1\&cid=pdf-reference\#references_tab_contents You may need to log in to JSTOR to access the linked references.

JSTOR is a not-for-profit service that helps scholars, researchers, and students discover, use, and build upon a wide range of content in a trusted digital archive. We use information technology and tools to increase productivity and facilitate new forms of scholarship. For more information about JSTOR, please contact support@jstor.org.

Your use of the JSTOR archive indicates your acceptance of the Terms \& Conditions of Use, available at https://about.jstor.org/terms

Cambridge University Press is collaborating with JSTOR to digitize, preserve and extend access to International Journal of Middle East Studies 


\section{Hootan Shambayati}

\section{A TALE OF TWO MAYORS: COURTS AND POLITICS IN IRAN AND TURKEY}

Countries such as Iran and Turkey do not fit comfortably into the democratic and authoritarian categories. In these countries, elections are held regularly, and the will of the people is accepted as one source of sovereignty. At the same time, both constitutionally and in practice the elected officials have to share the exercise of political power with institutions that do not draw their power directly from the will of the people. In such systems, the judiciary has two important political functions. First, the judiciary acts as a politically insulated decision-maker through which the unelected head can exercise some degree of control over the actions of the elected head. Second, the judiciary's direct involvement in the political arena increases political tensions and legitimates the continuation of the two-headed system. In systems based on divided sovereignty, the tensions created by the judicialization of politics contribute to the stability of the regime.

Two caveats, however, are in order. First, a double-headed executive system is not a necessary condition for the judicialization of politics. Judicialization of politics is also common in a number of countries with single-headed executive systems, such as the United States. However, as the discussion here suggests, the conditions for judicialization of politics are particularly ripe in countries with divided sovereignty. Second, the political systems in Turkey and Iran are not exactly the same. Having begun its first democratic experience in 1945, and despite three formal military interventions (1960, 1971, and 1980), Turkey is an old democracy among developing countries. Despite this long experience with democracy and democratic institutions, however, Turkish democracy remains unconsolidated. Iran's experience with democratic institutions is much shorter in duration. Although since the Constitutional Revolution of 1906-1907 Iran has periodically experimented with free elections and multi-party politics (1907-21 and 1941-53), these experiments have generally been short-lived. The victory of Mohammad Khatami in the presidential elections of 1997 and 2001 has once again opened the political system. Iran's overall political system nevertheless continues to display strong authoritarian tendencies. In short, Turkey is an unconsolidated democracy, while Iran is an unconsolidated authoritarian regime. Despite the differences, however, the Iranian and Turkish political systems have enough similarities to warrant a comparison. As I will show, these similarities include a commitment to constitutionalism, division of sovereignty between elected and unelected institutions, and the prominence of the judiciary in the political arena.

Hootan Shambayati is Assistant Professor in the Department of Political Science and Public Administration, Bilkent University, 06533 Bilkent, Ankara, Turkey; e-mail: hootan@bilkent.edu.tr. 
The first two sections of the article develop the theoretical framework of the study. I will then look at the constitutional structures of Iran and Turkey and discuss the role assigned to the judiciary in the two systems. The final section examines the politically important court cases of Recep Tayyip Erdoğan, a former mayor of Istanbul (1994-98), and his Iranian counterpart Gholamhussein Karbaschi, a former mayor of Teheran (199098). However, at the outset I should point out that my interest is not in establishing the guilt or innocence of the individuals involved. Rather, I hope that the analysis provided here will shed some light on the role of the judiciary in the politics of countries with two-headed executives.

\section{JUDICIALIZATION OF POLITICS AND REGIME STABILITY}

Some observers view the active role of the courts in the political arena, particularly in developing countries, as a manifestation of the politicization of the judiciary. Such a view implies that the courts are dependent on political actors. Judicialization of politics, however, assumes that the judiciary enjoys some level of independence vis-à-vis other political actors. Whereas politicization of the judiciary points to the influence of political actors in the judicial arena, judicialization of politics refers to the expansion of the judiciary's political role. Although the expansion of the political role of the judiciary is a global reality, its consequences are not clear. In a democracy, of course, the judiciary plays an important role in both maintaining the rule of law and safeguarding the rights of the citizens. As Larry Diamond notes, "[E]lected executives, state bureaucrats, soldiers, and police cannot be held accountable without a judicial system that has the constitutional and political autonomy to ensure a genuine rule of law."' The judiciary not only serves as an obstacle to the tyranny of the majority; it also serves as an important restraint on the activities of the other branches of the state and provides an additional mechanism of accountability.

These goals are often achieved through "judicial review," the power of the courts to rule on the legality of the actions of the other branches of government. Despite the general recognition that some form of judicial review is desirable, if not necessary, for the functioning of democratic regimes, the practice remains controversial. First, of course, the power of an unelected and politically insulated judiciary to review the actions of popularly elected branches of government is in tension with the ideal of popular sovereignty, which is at the heart of democracy. Second, critics warn that the judiciary's active involvement in policy-making undermines the democratic process. When the regime-supporting coalition loses its cohesion, political actors will try to remove controversial issues from the political agenda by referring them to the courts or other so-called neutral institutions. While the objective is to decrease political tensions, such practices can lead to further polarization and can accelerate the breakdown of the regime. ${ }^{2}$ As Juan Linz notes, "The legitimacy of having judicial bodies make what are essentially political decisions in a democracy is always doubtful, and in countries where judicial bodies have been established only recently, their judgment is even less likely to be considered binding." 3

The authority of "neutral" institutions in making binding political decisions is further undermined by the loss of impartiality. Although institutions such as the judiciary might remain structurally independent, their active participation in the decision-making process 
undermines their ability to act as impartial arbiters. ${ }^{4}$ Over-reliance on the courts can fan political tensions and further undermine the cohesiveness of the polity.

The effects of judicialization of politics on non-democratic regimes are less clear. In general, we tend to associate an independent judiciary with democracy. ${ }^{5}$ However, authoritarian regimes, too, might be willing to work with an independent judiciary. First, a strong and independent judiciary can be an effective instrument of ensuring that lower-ranking officials implement decisions made at the top. ${ }^{6}$ Second, there might be a general convergence of views between the members of the judiciary and the authoritarian leadership. ${ }^{7}$ Furthermore, an authoritarian regime, unlike a democratic one, which at least in theory has to abide by the rule of law, might not feel obligated to implement the decisions of a disagreeable judiciary. Finally, an independent judiciary can provide the authoritarian regime with some level of legitimacy. ${ }^{8}$ Nevertheless, the available data, although limited, suggests that the breakdown of authoritarian regimes follows a pattern similar to that of democratic regimes as far as the role of the judiciary is concerned. ${ }^{9}$

In short, in both democratic and non-democratic regimes, over-judicialization of politics indicates and contributes to tensions that can undermine the stability of the system and lead to the breakdown of the regime. As tensions increase, those who lose in the electoral and legislative processes might appeal to the courts for a more favorable outcome. At the same time, political leaders might prefer to refer highly contentious political issues to the courts, or to court-like institutions, to prevent an open split among the ruling elite.

Relying on the judicial process to resolve divisive political issues not only is unlikely to reduce tensions, but it has the potential of creating new ones. The legislative process, particularly in democracies, is based on bargaining and compromise. It creates neither absolute winners nor absolute losers. The judicial process, however, is based on finding "Truth" and establishing guilt. The judicial process creates absolute "winners" and "losers." As Stephen Krasner notes, "[J]udicial procedures are designed to judge the guilt or innocence of individuals, but developing stable democratic societies... requires[s] prudent political calculations, not judicial findings." ${ }^{10}$ Reliance on the judicial process to resolve political issues undermines support for the regime and can pose a threat to the consolidation of democracy.

\section{DIVIDED SOVEREIGNTY}

Many modern regimes are hybrids of electoral democracy and authoritarianism. ${ }^{11}$ In hybrid regimes, an elected executive and unelected institutions jointly exercise sovereignty. In many cases, the military forces constitute the unelected executive, but as the Iranian example shows, this need not be the case. Although the military, because of its access to the means of violence and its hierarchical structure, is obviously more capable of performing the role of an unelected partner in the exercise of power, some civilian institutions, such as a well-entrenched religious establishment, might also be capable of fulfilling this function.

Political systems based on divided sovereignty are distinguished from authoritarian and democratic regimes by two characteristics. First, unlike in purely democratic or purely authoritarian systems, the two heads jointly exercise power. While it is true that the unelected head limits the powers of the elected head, the latter's powers are not residual. Elections are held regularly; governments change as a result of these elections; and the 
elected governments, both in theory and in practice, render considerable power. Elections in such countries are not mere window-dressing, as is often the case in authoritarian systems. Nor are the elected governments mere puppets. The unelected head, despite its privileged position, cannot ignore the results of elections or the powers of the elected head. Although the unelected head might be able to influence policy on a large number of issues, it cannot ensure the outcome of the policy-making processes. In other words, unlike in authoritarian systems, there is a high level of uncertainty, and the unelected head cannot get its way all the time. ${ }^{12}$ At the same time, however, the elected executive has to share power with an unelected executive.

Second, systems of divided sovereignty, or what Daniel Brumberg calls "dissonant institutionalization," by definition embody a high level of tension. The adoption of a system based on divided sovereignty itself indicates a division in the ruling coalition concerning the nature of sovereignty. As Brumberg notes, "[D]issonant institutionalization occurs when competing images of political community and the symbolic systems legitimating them are reproduced in the formal and informal institutions of state and society." 13 This institutionalization of competing ideologies means that the political structure will continue to generate tensions and encourages conflict within the polity. These tensions, however, are not necessarily destabilizing and are needed for the survival of the overall system. If the tensions between the two heads of the system are resolved in favor of either one of them, the system will experience an out-of-type transformation. It will either become fully democratic or fully authoritarian. A regime based on divided sovereignty must prevent social and political tensions from boiling over and threatening the stability of the system while generating enough tension to justify the continued presence of both heads of the executive.

These regimes use a number of tactics to achieve this mix. One common tactic is to try to remove potentially controversial issues from the political agenda by relying on detailed constitutions and legal codes. A second useful tactic is the referral of potentially controversial issues to formally sanctioned, but "non-political," autonomous policy-making bodies. ${ }^{14}$ Both tactics tend to encourage a more active political role for the judiciary. Heavy reliance on detailed constitutions and legal codes automatically expands the powers of the judicial bodies that have to interpret and implement the laws. Furthermore, a politically "insulated" judiciary can be an effective restraint on the powers of the elected head. Hence, it is not surprising that out-going authoritarian regimes often try to pack the judiciary with their supporters as a means of guaranteeing their privileges after the transition. ${ }^{15}$

Another important function of the courts in systems based on divided sovereignty is the control and creation of tensions that are necessary in legitimating the regime. A state based on divided sovereignty lacks a hegemonic ideology and "can become vulnerable to efforts by competing social forces to radically redefine its ideological foundations." 16 As the examples of Turkey and Iran show, the appearance of these social forces encourages the state-or, at least, those parts opposing change - to turn to the courts. Taking potentially divisive political issues to court might prevent an open confrontation between the two heads. However, as this article suggests, the population at large might not find the courts' politically significant decisions binding. The instability created by this disregard for legal decisions in turn tends to justify the unelected head's threat perception and to justify the continuation of its guardian role. Thus, what appears to be regime-threatening 
political instability becomes a mechanism for preserving the division of sovereignty between elected and unelected institutions.

\section{THE CONSTITUTIONAL STRUCTURE OF IRAN AND TURKEY}

Shortly after the success of the Iranian Revolution of 1978-79, a clergy-dominated assembly was elected to prepare a constitution suitable for the new regime. ${ }^{17}$ After receiving Ayatollah Khomeini's support, the draft constitution was submitted to a national referendum on 2-3 December 1979. According to official figures, it received 15,680,339 positive votes against 78,516 negative votes. ${ }^{18}$ Support for the constitution was closely linked to the personal popularity of Ayatollah Khomeini, who automatically assumed the highest position in the system as the Supreme Leader.

As students of Iranian politics are well aware, the Islamic Republic simultaneously displays totalitarian, authoritarian, and democratic tendencies. ${ }^{19}$ The openness of Islam to different interpretations and the pluralism of the politicized sections of the religious elite has prevented the development of a full-fledged totalitarian system, and combined with Iran's constitutional tradition and the mass mobilization of the revolution, it has encouraged competitive politics. ${ }^{20}$ Iranian voters have genuine, although limited, choices in parliamentary and presidential elections, making Iran unique among non-democratic countries. Furthermore, parliamentary debates are often passionate and challenge the executive. ${ }^{21}$ At the same time, however, both the Parliament and the president are subject to the limitations imposed by the Supreme Leader. As H. E. Chehabi notes, "[W]hile the regime is somewhat responsive to the citizenry, it is not accountable to a demos."22

According to the constitution, absolute sovereignty belongs to God. However, the constitution also provides a role for the people in the exercise of sovereignty. It reads,

Absolute sovereignty over the world and man belongs to God, and it is He who has made man master of his own social destiny. No one can deprive man of this divine right, nor subordinate it to the vested interests of a particular individual or group. The people are to exercise this divine right in the manner specified in the following articles. [Article 56]

Accordingly, the constitution creates the office of the Supreme Leader of the Revolution. Article 5 of the constitutions stipulates that "During the Occultation of the Wali al-Asr (may God hasten his reappearance), the wilayah and leadership of the Ummah devolve upon the just ['adil] and pious [muttaqi] faqih, who is fully aware of the circumstances of his age; courageous, resourceful, and possessed of administrative ability, will assume the responsibilities of this office." Article 57 charges the Supreme Leader with the duty of supervising the executive, the legislative, and the judicial branches. At the same time, however, the constitution also endorses the principle of popular sovereignty and representative government by creating a popularly elected legislature and presidency (Articles 114 and 62, respectively).

Over the past twenty years, Iran has devised a number of mechanisms to deal with tensions created by this dichotomy. During Khomeini's tenure as the Supreme Leader, his personal charisma was used to diffuse the tension, while institutions such as the Guardian Council (shurayi negahban), half of whose members must be Islamic jurists appointed by the Supreme Leader, reviewed all laws passed by the legislature to ensure their conformity with Islamic principles. Another example is the Regime's Expediency 
Council (majma 'i tashkhis-i maslahat-i nizam), which is charged with resolving conflicts between the legislature and the Guardian Council. Finally, of course, it is the Supreme Leader himself who is the ultimate arbiter of disputes among the various institutions of the state. ${ }^{23}$

A similar dual executive system, although with important differences, is in operation in Turkey under the 1982 constitution. The 12 September 1980 military coup took place at a time that the Turkish political system appeared paralyzed and political violence had become a daily problem. Hence, the coup and its leadership enjoyed a high level of support among the population. From the beginning, the generals made it clear that they did not intend to stay in power indefinitely and that they intended to return power to elected civilian politicians in the near future. They also made it clear that the status quo ante was unacceptable and that they intended to restructure Turkish politics. To prevent the political polarization that was blamed for the problems of the 1970s, they introduced a new constitution and put in place a number of new laws and regulations that could not be amended by future governments.

After the coup, the five generals who had staged the coup reconstituted themselves as the Council of National Security (CNS) ${ }^{24}$ and convened a special assembly to compose a new constitution. Notably absent from the assembly were politicians, most of whom had been banned after the coup. The assembly presented the draft of the new constitution to the CNS, where it was further modified before being formally adopted in a national referendum on 7 November 1982. Some 91.27 percent of the electorate took part in the referendum and gave the constitution an overwhelming approval rating of 91 percent. ${ }^{25}$

A number of steps were taken to ensure a high approval rating in the constitutional referendum. All eligible Turkish citizens were legally required to participate in the referendum. Failure to do so would have disqualified them from participating in the next parliamentary elections. Approval of the constitution was linked to support for the popular leader of the coup, General Kenan Evren. General Evren personally took over the task of officially explaining the draft constitution to the public. Furthermore, the approval of the constitution meant that General Evren would automatically become the president of the Republic for a seven-year term. ${ }^{26}$ Finally, like its Iranian counterpart, the Turkish constitution was adopted under extraordinary conditions, and support for it represented a desire for return to normalcy. ${ }^{27}$

The 1982 constitution established "a dual system of executive decision making." ${ }^{28}$ The exercise of political power is shared between the popularly elected civilian authorities and the military. This duality is also well recognized by the general public, who make a sharp distinction between the popularly elected civilian leadership constituting the government (hükümet) and the military-dominated state (devlet). While the constitution establishes a parliamentary democracy based on popular sovereignty, it limits the exercise of popular sovereignty by providing for the formal participation of unelected actors in the decision-making process.

An important manifestation of this duality is the ambiguous position of civilian institutions with regard to the armed forces. The most important constitutional instrument of the armed forces' involvement in the political arena is the National Security Council (Milli Güvenlik Kurulu). The National Security Council (NSC) first received formal recognition in the military-inspired 1961 constitution that was put in place after the 1960 military coup. From the beginning, the NSC was envisioned as a forum for joint policy-making 
by military and civilian officials. A series of constitutional amendments adopted after the military intervention of 1971 curbed some of the freedoms guaranteed by the constitution and augmented the powers of the NSC. The 1980 military intervention led to further strengthening of the military's role in the decision-making process. Article 118 of the 1982 constitution enumerates the membership and the duties of the NSC:

[t]he National Security Council shall be composed of the Prime Minister, the Chief of the General Staff, the Ministers of National Defense, Internal Affairs, and Foreign Affairs, the Commanders of the Army, Navy, and the Air Force, and the General Commander of the Gendarmerie, under the chairmanship of the President of the Republic.

Depending on the particulars of the agenda, Ministers and other persons concerned may be invited to meetings of the Council and their views be heard.

The National Security Council shall submit to the Council of Ministers its views on taking decisions and ensuring necessary coordination with regard to the formulation, establishment, and implementation of the national security policy of the State. The Council of Ministers shall give priority consideration to the decisions of the National Security Council concerning the measures that it deems necessary for the preservation of the existence and independence of the State, the integrity and indivisibility of the country, and the peace and security of society [emphasis added].

The new constitution specified who the civilian members of the NSC were and ensured the numerical equality of the civilian and military members. The Parliament could no longer increase the number of civilians on the council through ordinary legislation. ${ }^{29}$ The constitution instructs the cabinet to give "priority consideration to the decisions of the National Security Council." ${ }^{30}$ Under this system, the NSC no longer makes "recommendations"; instead, it makes "decisions." The NSC has a permanent secretariat, thus making it a permanent actor in the decision-making process. While the "decisions" of the NSC are theoretically only advisory, and the final decision for their implementation is left to the council of ministers and Parliament, it is clear that the framers of the constitution conceived of the NSC as an important actor in the decision-making process. ${ }^{31}$ As one observer has noted, "[Under the 1982 constitution], far from returning to the barracks, the military retained considerable influence over governmental policy making through its majority representation in the National Security Council." 32

The NSC enjoys wide-ranging discretion in setting the agenda for its monthly meetings. Through the mechanism provided by the NSC, the military leadership has participated in making policies that range from lifting the parliamentary immunity of the members of the (pro-Kurdish) Democratic Party to offering Arabic in secondary schools, and from stand-by agreements with the International Monetary Fund to bank failures. ${ }^{33}$ The wide range of topics covered by the NSC has meant that there has been a high level of tension between the military and the civilian leadership, irrespective of the political ideology of the government in power. However, this does not mean that the Turkish military has been able to "get its way" in every decision. Nor does it mean that the military is involved in every decision made. In contrast to the decisions of the Iranian Supreme Leader, the decisions of the NSC are only "advisory," and their final implementation is left to the civilian politicians in the cabinet and Parliament. In many instances, the civilian leaders, ever mindful of their popularity, have resisted the wishes of the military. ${ }^{34}$ This resistance, however, is often used by the military as a sign of the "irresponsibility" of the civilian politicians who are willing to support the decisions of the NSC on paper but then fail to implement them..$^{35}$ 
In sum, Iran and Turkey have two-headed political systems in which executive power is jointly exercised by popularly elected officials and by institutions drawing their legitimacy from sources other than popular sovereignty. While in the Turkish case the exercise of sovereignty by the elected officials is subject to the approval of the militarydominated NSC, in the Iranian case it is the Supreme Leader who limits the power of the elected president. ${ }^{36}$ The extent to which the unelected head actively participates in the decision-making process varies across issue areas and time. The potential for the unelected partner's involvement in the decision-making process, however, is always present. The result is that a high level of tension is inherent in the political system of both countries.

One consequence of the division of sovereignty is a tendency toward the depoliticization of political issues by trying to remove controversial issues from the political arena. The length of the Iranian and Turkish constitutions (177 articles each) and the details into which they go in discussing political, social, and economic issues is to a large extent a reflection of the desire of the framers of these constitutions to remove a number of issues from the political arena. This distrust for politics is also reflected in constitutionally sanctioned non-political specialized agencies, councils, and boards that are found in the two countries. In the Iranian case, the constitution sanctions both a Guardian Council, consisting of six Islamic jurists appointed by the Supreme Leader and six jurists selected by Parliament from a list proposed by the head of the judiciary, himself appointed by the Supreme Leader, and the Regime's Expediency Council, whose members are appointed by the Leader (Articles 91 and 112, respectively). While the first is charged with the duty of reviewing legislation to ensure its conformity to Islamic principles and the constitution, the second is given the task of resolving differences between Parliament and the Guardian Council (Articles 4 and 112, respectively).

Reliance on non-political councils is even more pronounced in the Turkish case, where there are constitutionally sanctioned specialized councils or boards to arbitrate strikes (Article 54), supervise elections (Article 89), and administer institutions of higher education (Articles 130-32). There is also a separate body to supervise radio and television broadcasts. What is significant about these boards and councils is that the elected political branches have little control over their membership. The members of the Higher Education Council (Yüksekögrretim Kurulu), which supervises all matters related to higher education, for example, are appointed by the president of the Republic, a non-partisan office holder, from among candidates nominated by the Council of Ministers, the Chief of the General Staff of the military, and the universities (Article 131). ${ }^{37}$

Finally, the desire to rely on neutral institutions to resolve essentially political issues is also reflected in the structure and functions of the judiciary. As I discuss in the next section, in both Iran and Turkey the judiciary is assigned a wide range of political roles, which it performs in isolation from the political head of the executive branch. At the same time, however, the judiciary is expected to perform these functions in accordance with the views of the unelected head.

\section{DIVIDED SOVEREIGNTY AND THE JUDICIARY}

The structural independence of the judiciary is constitutionally guaranteed in both Turkey and Iran. However, independence in both cases means only political insularity of the 
judiciary from the popularly elected executive. The views of the unelected head are made known not only through public announcements and frequent "briefings" given to the various groups, including members of the judiciary, but also through a socialization and selection process that - at least, at the higher levels of the judiciary-reproduces the desired ideology and values among the courts' personnel.

This is most clear in the Iranian case, where, according to Article 157 of the constitution, the head of the judiciary is appointed by the leader of the Revolution without any formal input from the elected president or Parliament. According to Article 156 of the constitution, "the Judiciary is an independent power." The constitution further addresses the structural independence of the judiciary in Article 164:

[a] judge cannot be removed, whether temporarily or permanently, from the post he occupies except by trial and proof of his guilt, or in consequence of a violation entailing his dismissal. A judge cannot be transferred or redesignated without his consent, except in cases when the interest of society necessitates it, that too, with the decision of the head of the judiciary branch after consultation with the chief of the Supreme Court and the Prosecutor General.

At the same time, however, the judiciary is expected to follow a certain ideological line. The preamble of the constitution defines the role of the judiciary in following terms:

[t]he judiciary is of vital importance in the context of safeguarding the rights of the people in accordance with the line followed by the Islamic movement, and the prevention of deviations within the Islamic nation. Provision has therefore been made for the creation of a judicial system based on Islamic justice and operated by just judges with meticulous knowledge of the Islamic laws. This system, because of its essentially sensitive nature and the need for full ideological conformity, must be free from every kind of unhealthy relation and connection.

Thus, independence from political influences is seen as a guarantee that the judiciary will enforce the correct ideological line. While judicial independence is valued, the constitution sees the judiciary as the enforcer of the ideological line defined in practice by the Supreme Leader. To achieve this mixture, the judicial branch and the security forces are cut off from the legislature and the elected executive. The fact that the judiciary has an official head and his direct appointment by the leader of the Revolution suggest that the judicial branch is viewed as an equal, or perhaps even superior, partner of the elected executive and legislative branches. The superiority of the judiciary is also alluded to by the head of the judiciary's role in the appointment of the minister of justice, a member of the president's cabinet. According to Article 160 of the constitution, the minister of justice is chosen from among candidates nominated by the head of the judiciary.

Although the judicial branch in Iran does not have the power of judicial review, a power that is specifically reserved for the Guardian Council, it is constitutionally assigned certain duties in supervising the activities of the elected head of the executive branch. The head of the judiciary supervises the proper implementation of the laws and along with the president and speaker of Parliament supervises the state-controlled radio and television (Articles 156 and 175, respectively). He is to draft judicial laws fitting for the Islamic Republic (Article 158), and he reviews the accumulation of wealth by highranking members of the executive branch. The head of the judiciary is also a member of Iran's NSC, and in the case of the Supreme Leader's untimely death or incapacitation will serve on the Leadership Council (Articles 142 and 111, respectively). The judiciary is also formally represented on the council for the Revision of the Constitution (Article 177). 
Hence, the constitution formally assigns a number of political functions to the judiciary while attaching it to the unelected head of the political system.

A similar phenomenon can be seen in the Turkish case. Article 138 of the 1982 constitution guarantees the independence of the judges by prohibiting outside interference in the adjudication of disputes and forbids the National Assembly from discussing the cases before the courts. The constitution also guarantees security of tenure for judges and public prosecutors and provides them with a high degree of internal autonomy in personnel matters through the constitutionally sanctioned Supreme Council of Judges and Public Prosecutors (Article 159). ${ }^{38}$

The length to which framers of the Turkish constitution were willing to go to insulate the judiciary against pressure from politicians is perhaps nowhere more clear than in the appointment process to the Constitutional Court (Anayasa Mahkemesi). The court not only has the power of judicial review; it also has a number of other political functions, including the power to try high-ranking officials and to supervise political parties. These principles were first introduced in the 1961 constitution, in which a Constitutional Court modeled after the German Constitutional Court was created. ${ }^{39}$ In the German case, the two houses of Parliament appoint the sixteen members of the Federal Constitutional Court. Furthermore, while six of them are drawn from the judges serving on the federal bench, the political parties nominate the other ten. The German constitutional court stands out as a "political court." 40

In contrast, political branches do not have a direct role in determining the composition of the Constitutional Court in Turkey. Seven of the eleven members and three of the four substitute members of the court are appointed by the president of the Republic from among candidates nominated by the High Court of Appeals (Yargitay), the Council of State (Danıştay), the Military Court of Appeals (Askeri Yargıtay), the High Military Administrative Court (Askeri Yüksek Îdare Mahkemesi), and the Court of Accounts (Sayıstay). The president also appoints one member from among academic personnel of the universities nominated by the Higher Education Council and three members and one substitute from among high civil servants and lawyers (Article 146). In short, professional judges and senior civil servants dominate the Turkish Constitutional Court. Influence of political parties is also limited by the fact that the presidency under the 1982 constitution is a non-partisan office and the fact that the constitution does not foresee any role for the prime minister and the cabinet, or Parliament, to influence appointments to the court.

Despite its non-political composition, the court has political functions. In addition to the judicial review of legislation, the Constitutional Court is also the venue for the trial of the president of the Republic, members of the council of ministers, members of Parliament, members of the Constitutional Court itself and the other high courts, public prosecutors, and the members of the Supreme Council of Judges and Public Prosecutors (Article 148). The court is also responsible for overseeing political parties and for dissolving those political parties found in violation of the Constitution or the Political Parties Law (Article 69), a function that it has exercised with zeal, closing seventeen political parties since 1983. ${ }^{41}$ As Yekta Güngör Özden, at the time the president of the Constitutional Court, noted, "[T] he functions of the court are of a political character." 42 Similarly, Mehmet Turhan, a rapporteur at the Constitutional Court, notes, "[T]he judiciary [is] given a considerable power in the exercise of sovereignty," with the aim of "put[ting] an end to the principle of the supremacy of the Parliament." 43 
The judiciary's political functions are also exercised through special courts, particularly the State Security Courts (Devlet Güvenlik Mahkemeleri). State Security Courts (SSCs) were first organized in the 1970s but were shut down by the Constitutional Court for violating the constitutional guarantee of trial before a constitutionally designated judge. They were resurrected under Article 143 of the 1982 constitution "to deal with offences against the indivisible integrity of the State with its territory and nation, the free democratic order, or against the Republic whose characteristics are defined in the Constitution, and offences directly involving the internal and external security of the State." These courts are presided over by a three-judge panel. Until June 1999, when the constitution was amended, one of the judges was an active-duty military officer serving on the military courts. ${ }^{44}$ The vagueness of the term "internal and external security of the state" means that SSCs deal with a wide range of issues, including terrorism, freedom of expression, organized crime, bank failures, and corruption.

Like its Iranian counterpart, the Turkish judiciary sees itself as the defender of the regime in power. The chief justice of Turkey's Constitutional Court opened the 1993 session by noting that "the Constitutional Court was the guardian of the regime" and that "the state that does not protect itself is not a state." 45 This sentiment is also shared by Turkey's current minister of justice, who in February 2001 referred to the Court of Cassation Chief Prosecutor's Office as the "guardian of the regime." 46 The Turkish judiciary sees itself as the defender of such concepts as republicanism, secularism, the indivisible integrity of the state, and democracy. These concepts are enumerated in the constitution, but their meaning is, of course, subject to interpretation. Although few judiciaries can match the Iranian record of the past few years, the Turkish judiciary's presence in the political arena is a constant feature of Turkish political life.

In both Iran and Turkey, provisions are in place to insulate the judiciary from political pressure from elected officials. In neither country, however, is the judiciary an "impartial" actor when it comes to matters concerning the state. As it is discussed in the next section, in recent years both Iran and Turkey have witnessed a growing split between the views of the two heads of the executive. One manifestation of this split has been the expansion of the judiciary's political role. In both countries, the unelected head has relied on the judiciary to target popular politicians and political movements.

\section{THE JUDICIARY IN ACTION}

Iran's political system was put to the test by the victory of Mohammad Khatami in the presidential election of May 1997. In a relatively free election by Iranian standards, Khatami won a landslide majority against the candidate publicly endorsed by Ayatollah Khamenei, the Supreme Leader of the Revolution. He won by attracting the support of the younger generation through a campaign promising more personal and cultural freedoms. Khatami's victory was interpreted as a rejection of the Supreme Leader and his control of the political system. In the words of the French diplomat and journalist Eric Rouleau, "[T]he cohabitation between the faqih Ayatollah Khamenei, the supreme politico-religious authority, and President Mohammad Khatami has come to resemble a multi-faceted guerrilla war." ${ }^{47}$ President Khatami has seen his proposals defeated by the so-called conservatives supported by the Supreme Leader who controlled Parliament until the parliamentary elections of February 2000, while the judiciary has shut down 
pro-Khatami newspapers ${ }^{48}$ and increased its scrutiny of Khatami's political allies, including trying and imprisoning Gholamhussein Karbaschi, the former mayor of Tehran.

Born in 1955 to a clerical family, Gholamhussein Karbaschi belongs to a younger generation of politicians. Before the revolution he had studied mathematics at the university while also taking part in classes at religious seminaries. After Khomeini's triumphant return to Iran in January 1979, Karbaschi worked on Khomeini's personal staff and attracted the ayatollah's attention. His career took off in 1982, when at age twenty-seven Ayatollah Khomeini appointed him the governor of Isfahan, one of Iran's most important provinces. The years in Isfahan gained Karbaschi a reputation as someone who could get things done. He was widely praised for his work, particularly for restoring the city of Isfahan's historic beauty and charm. In 1990, he was appointed as the mayor of Teheran by President Ali Akbar Hashemi-Rafsanjani.

Karbaschi's popularity continued to increase as mayor, although his policies also generated considerable controversy. Under his leadership, public services were improved and new roads and parks were built. The roots of Karbaschi's popularity, however, are much deeper than these material improvements suggest. As Fariba Adelkhah notes, "Karbaschi has been at the point where spirituality ( $m a$ ' $a d)$ and material things ( $m a$ 'ash) converge.... [H]e has in practice been opening up a space for all sorts of practices which. . . involve reshaping the private and public spheres." 49

On 17 January 1996, only three months before the parliamentary elections, Karbaschi and fifteen other technocrats associated with the reform policies of President HashemiRafsanjani formed Kargozaran-i Sazandigi (Executives of Construction) and entered the campaign in support of the "reformist" candidates. The group showed its true political potential in the May 1997 presidential elections when it supported the victorious campaign of Mohammad Khatami. Karbaschi mobilized the resources of the Tehran municipality in support of the campaigns of Khatami and other reformist candidates. ${ }^{50}$ Particularly important was the municipality's popular daily Hamshahri, which, "through its support for Khatami, probably brought out more voters than any campaigning could have done." 51 Ideologically, Karbaschi and other members of the Executives of Construction belong to what Farhang Rajaee has described as "Islamic yuppies." They want to modernize Iran without Westernizing it. They might be political liberalizers within the Iranian context, but, like other liberalizers, they have no intention of overthrowing the existing system. ${ }^{52}$

In July 1997, shortly after the presidential elections, in response to a call from the Supreme Leader to intensify the fight against corruption, offices of the Tehran municipality were raided and a number of high-ranking officials were taken into custody. Karbaschi himself was arrested in April 1998. ${ }^{53}$ His arrest was met with wide-scale public demonstrations and was interpreted as another assault by the conservatives on the reform policies of President Khatami. The public's reaction forced Ayatollah Khamenei to ask the heads of the three branches (Ayatollah Yazdi, representing the judiciary; the speaker of Parliament and defeated presidential candidate Nateq-Nouri; and President Khatami), along with the chairman of the Expediency Council (former President Hashemi-Rafsanjani), to find a solution to the crisis. They recommended that Karbaschi be released from prison while awaiting trial for corruption and embezzlement. ${ }^{54}$ Karbaschi's trial began on 6 June 1998 and concluded with a guilty verdict on 23 July 1998.55

In his court defense, Karbaschi admitted that mistakes might have been made and that high-ranking municipal officials had been given special privileges. However, he 
justified these privileges by arguing that it was for the good of the country, that such practices were common in all government institutions, and that without such practices the administration would not be able to attract qualified personnel. ${ }^{56}$ At the end, however, he was found guilty of embezzlement and misuse of government funds. The court sentenced him to five years in jail and sixty lashes (suspended). He was also ordered to return 1.6 billion rials to the municipality and to pay a fine of 1 billion rials. Most important, he was barred from holding any public office for a period of twenty years. On appeal, the jail term was reduced to two years, and he was barred from politics for ten years. The lashes were converted into a monetary fine.

Despite the conviction, public support for Karbaschi has been strong. The trial was televised nationwide, and millions of Iranians remained glued to their TV sets for the duration of the trial. The verdict against the mayor was met with public demonstrations and letters and editorials in the media in support of the mayor. ${ }^{57}$ Most interesting, however, reformist political figures, including President Khatami, continued to support Karbaschi. In a phone conversation with Karbaschi's wife the day after his imprisonment, the president expressed his dissatisfaction with the outcome of the trial and his regrets "that the country is deprived of [Karbaschi's] services for the time being." 58 The conservatives reacted to the continued support for Karbaschi and the attempts to free him from prison by pointing to the contradiction between talking about the rule of law and civil society, two favorite themes of President Khatami, and asking for clemency for a convict. The Tehran Times, for example, chastised both President Khatami and Hashemi-Rafsanjani for expressing "regret" over Karbaschi's conviction, ${ }^{59}$ while Resalat wrote,

The most important gain of the trial of Mr. Karbaschi was not the conviction of a violator or a member of the rival political group but the revelation of the faces of the "factionalists" who claim to be "law abiding."... The factionalists claiming to be law abiding once again have auctioned off all their past claims and are now building trenches against the law. Apparently, in the civil society claimed by these gentlemen, "law" is the first and last word. But will anything remain of civil society by pursuing this method?"60

Under pressure from both the public and the reformers, Ayatollah Khamenei pardoned Karbaschi on 25 January 2000. ${ }^{61}$ Continued support for Karbaschi is particularly interesting not only in that it is coming from sources high within the regime but also in that he was convicted of embezzlement and mismanagement of public funds. This outcome suggests that the Iranian public has rejected the moral authority of the courts in making judgments and dispensing punishment. The Iranian courts share this problem with their Turkish counterparts.

Turkey's dual-executive system was first challenged in the 1983 parliamentary elections, when in a three-party race the Motherland Party led by the late Turgut Özal emerged victorious, even though the military had declared its preference for another party. Although Özal was not the military's candidate, the military did not find him objectionable as prime minister. First, Özal was well known to the military and had served as deputy prime minister in charge of economic affairs under the military regime. Second, Özal and his Motherland Party did not openly challenge the privileged position of the NSC; nor did they try to amend the constitution radically. ${ }^{62}$ Finally, any potential reservations that the military might have had were mitigated by the fact that Özal had to 
serve under General Evren as president. By 1989, when Özal himself was elected to the presidency, he was clearly acceptable to the state.

A more severe shock was the victory of the Refah (Welfare) Party in the parliamentary elections of December 1995. An Islamist party, Refah was led by the veteran politician Necmettin Erbakan. Although it won only 21 percent of the national vote, it emerged as the single largest party in Parliament. After months of maneuvering by the "secularist" parties and the military to prevent Refah from coming to power, Erbakan formed a coalition government with former Prime Minister Tansu Çiller's True Path Party. Having failed to prevent Refah from coming to power, the state turned to the judiciary. Under pressure from the military, the coalition government resigned in June $1997 .{ }^{63}$ Refah was put on trial before the Constitutional Court for attempting to undermine Turkey's secular system and was closed on 16 January 1998. The closure of the Refah Party did not end the struggle against political Islam. An important part of this struggle has been attempts to undermine the local network of Refah and its successor, the Fazilet (Virtue) Party. ${ }^{64}$ In this regard, one of the most important steps was the trial and imprisonment of Recep Tayyip Erdoğan, the former mayor of Istanbul. ${ }^{65}$

Born in 1954, Erdoğan began his political career in the youth branch of Refah's pre1980 coup predecessor, the National Salvation Party (Milli Selamat Partisi). ${ }^{66}$ After the formation of Refah in 1984, he joined that party and become the head of its Istanbul branch. In 1994, Erdoğan was elected mayor of the greater Istanbul municipality.

Erdoğan's tenure as mayor was controversial. Under his leadership, as even critics agree, there was a marked improvement in municipal services. While some of these improvements were due to policies that were initiated before Erdoğan took office, it is generally agreed that he played a positive role. However, charges of corruption and mismanagement accompanied Erdoğan's successes, although all agree that neither corruption nor mismanagement is limited to Istanbul or the Islamists and that corruption is a problem in all Turkish public institutions irrespective of the political party or individual politician in charge. In general, it is also agreed that Erdoğan has not personally benefited from corruption. ${ }^{67}$

The legal case against Erdoğan was initiated because of a speech he had delivered on 6 December 1997 at a Refah-organized meeting in the city of Siirt, in southeastern Turkey, where Kurds form a significant part of the population. ${ }^{68}$ The location and timing of the speech made the Turkish authorities particularly sensitive to its content. The local prosecutor found the two lines of poetry with which Erdoğan had begun his speech objectionable. Taken from a poem by the famous Turkish poet and one of the intellectual fathers of Turkish nationalism, Ziya Gökalp (1876-1924), the lines in question are part of a fictional dialogue between the Emperor Romanus IV Diogenes (r. 1068-71) and the Selcuk Sultan Alparslan. In the first part of the poem, the Byzantine emperor declares, "I will burn the Koran, I will burn the Kaba; Those coming from the East will not see domes with minarets." In his speech, Erdoğan did not refer to the threat made by the emperor, but he went on to recite the sultan's response: "minarets are bayonets, domes helmets; mosques are our barracks, and the believers are soldiers." The rest of the speech was a typical political speech, in which Erdoğan pointed to his achievements as the mayor and the unfairness of criticisms directed against him, and mildly complained about Turkey's strict secularism and the restrictions put on public displays of religious sentiments. 
On 9 December 1997, the local prosecutor of the Republic filed charges against Erdoğan in Diyarbakir's State Security Court. The prosecution argued that the context in which the poem was used constituted a threat to the secular state and its institutions and was prosecutable under Article 312 of Turkish Penal Code, which prohibits "inciting people to hatred based on religion or race." In court, Erdoğan argued not only that the words were not aimed at inciting people to hatred, but that the poem belonged to one of Turkey's most important political thinkers and literary figures. He also noted that neither Gökalp nor the poem in question was banned, and that the poem was included in textbooks approved by the Ministry of Education. Erdoğan's defense team also found the lawsuit in violation of the Turkish constitution and the rulings of the European Court of Human Rights.

Nevertheless, in April 1998 the court found Erdoğan guilty as charged and sentenced him to ten months' imprisonment (under the current regulations he served four months) and payment of a fine. He was also banned from politics for life. The decision was upheld on appeal, and Erdoğan entered prison on 27 March $1999 .{ }^{69}$ He was released from prison in July 1999.

Erdoğan's conviction and subsequent incarceration were met with negative reactions from both his domestic supporters and the international community. The court verdict was met with large rallies in his support. There were also supportive demonstrations when he reported to prison to begin serving his sentence. He remained popular while in prison and was visited by a large number of supporters and political figures on a daily basis. Erdoğan's conviction also received a negative reaction from the international community. Even Turkey's staunch ally, the United States, issued a statement voicing its displeasure with the verdict and, in a public show of support for Erdoğan, dispatched its counsel-general in Istanbul, Caroline Hagins, to meet the embattled mayor the day after the verdict was confirmed by the Court of Appeals. After the meeting, Hagins noted that "such developments will weaken confidence in the Turkish democracy." 70 The verdict was also criticized by the European Union, various human-rights organizations, and the more liberal segments of the Turkish society, who, although not necessarily sympathetic to Erdoğan's political views, found the verdict incompatible with the basic principles of freedom of speech and democracy.

Despite the differences in charges against them and the fact that Erdoğan was elected whereas Karbaschi was appointed to his post, the two cases have a number of similarities. First, of course, is the fact that in both trials the accused was the mayor of the most important metropolitan center in his country. Karbaschi and Erdoğan used the resources of the municipality to build an extensive patronage network, which is potentially useful in both local and national politics. In the Turkish case, the economic liberalization of the 1980s was accompanied by attempts at administrative decentralization. ${ }^{71}$ As a consequence, by the end of the 1980s both the decision-making powers of the municipalities and their financial resources had been augmented, leaving the mayors in control of important redistributive and organizational mechanisms. A political party's control of a major municipality can put it in a privileged position in national politics by giving it access to a political machine capable of providing special services to its constituents. The Istanbul municipality, for example, not only is a major employer but has invested in a variety of economic enterprises. According to the former mayor, it also provides financial aid to 27,500 students. ${ }^{72}$ Refah-controlled municipalities, like municipalities controlled by 
other Turkish parties, have also been known to provide groceries, heating fuel, clothing, and so on to the poorer segments of society free of charge or at highly subsidized prices. Such practices, of course, not only provide services for the poor, they can also provide economic opportunities for the not so poor, and are important mechanisms for maintaining patron-client networks.

Similarly, under Karbaschi the Tehran municipality engaged in a variety of activities such as publishing; investing in various economic ventures, including some in other cities; providing direct or indirect support for political candidates; and so on. At one point, the Tehran municipality even made a grant to Columbia University in New York for the translation of the works of the Muslim historian Tabari. ${ }^{73}$ The municipality also "encouraged" businessmen to contribute to the campaigns of reformist candidates. When asked about this practice by the judge, Karbaschi replied that his aim was to "warm up" the campaign. ${ }^{74}$

Second, it is generally agreed that both Erdoğan and Karbaschi were relatively successful in improving municipal services. The success of the Refah Party in Turkey's 1995 national elections was due to the superior performance of the Refah mayors, particularly the mayors of large metropolitan centers of Istanbul and Ankara. As Jenny White has noted, "[I]n municipalities controlled by Refah buses run, the garbage is collected, and social services in general have improved." 75

Praise has also been strong for Karbaschi. For much of the past ten years he has been a poster boy for the Islamic Revolution and was portrayed as a capable manager transforming Tehran from a barely livable city to a modern metropolis. ${ }^{76}$ The Englishlanguage daily Tehran Times, which in general has not been friendly to Karbaschi, for example, noted in an editorial published shortly after the start of the trial that "there is no doubt that Karbaschi who has been suspended to act as mayor during the trial period has several feathers in his cap. No doubt he and his teammates have transformed the face of the sprawling capital of the Islamic Republic. No one can deny the fact that changes which have taken place for the better in Teheran's geographical and architectural features are praiseworthy."77

Third, at the time of their trials, both Erdoğan and Karbaschi were regarded as rising political stars with national appeal. Both his supporters and his detractors saw Erdoğan as one of the most dynamic leaders within the Islamic movement and as a potential replacement for the aging Necmettin Erbakan. Similarly, Iranian commentators saw Karbaschi as an increasingly important figure in Iranian politics.

Fourth, the reaction to these cases points to the failure of the legitimating functions of the Iranian and the Turkish judicial systems. Although both Erdoğan and Karbaschi were convicted in courts of law and served time in jail, and despite the political ban imposed on them, they have remained viable as political actors. Karbaschi continued to serve as the secretary-general of the Executives of Construction while in prison. ${ }^{78} \mathrm{~A}$ few days after his release he resumed his political activities by publishing a new newspaper, Hammihan, the first issue of which appeared shortly before the parliamentary elections of February $2000 .{ }^{79} \mathrm{He}$ was also given permission to establish a bank.

Similarly, the ban imposed on Erdoğan has not ended his political life. In 2001, Erdoğan led the reformist wing of the closed Virtue Party to form the Justice and Development Party, becoming one of its founding members and secretary-general. The Turkish Constitutional Court, however, ruled that as a banned politician Erdoğan could 
not be a founding member of a political party. The party removed Erdoğan's name from the list of its founders but kept him as secretary-general. Parliament changed the law to lift the political ban on politicians such as Erdoğan. Accordingly, Erdoğan was retried and reconvicted. The Supreme Election Board, composed of justices from the Court of Cassation and the Council of State, rejected Erdoğan's candidacy in the November 2002 elections because of the conviction. Nevertheless, the Justice and Development Party won a landslide victory and came to power with an absolute parliamentary majority. Unable to form a government himself, Erdoğan formed a caretaker government under his deputy, Abdullah Gül. The new Parliament moved quickly to amend the constitution to allow Erdoğan to take part in future elections. The Justice and Development Party also challenged the result of elections in the Kurdish-populated city of Siirt, where Erdoğan had recited the offending poem. The Elections Board accepted the challenge and scheduled new elections for 9 March 2003, allowing Erdoğan to stand as a candidate. His victory was certified on 11 March 2003, and he was allowed to take his seat in Parliament immediately. Within an hour, Prime Minister Gül handed in his resignation, and President Sezer promptly asked Erdoğan to form a new government.

Finally, the two cases discussed here and other similar cases are a manifestation of the loss of cohesion in the two polities. Erdoğan's trial was part of a larger crackdown on the Islamist movement in general. Similarly, as the Iranian journalist Morteza Mardiha points out, "[Karbaschi's trial] in reality was the trial of the modernizations of Hashemi ${ }^{80}$ and the modernity of Khatami, ... Karbaschi was arrested, humiliated, and convicted so that Hashemi and Khatami would learn a lesson and discover the sensitivities of their common rival." ${ }^{81}$ Karbaschi and Erdoğan are not anti-systemic politicians. ${ }^{82}$ In fact, they are products of the very system that convicted them. They were convicted not because of what they had done as individuals but because of the rising popularity of the political movements that they represented. They became targets of judicial proceedings only after elections produced results that were unacceptable to the guardians of the Turkish and Iranian regimes.

\section{CONCLUSION}

Students of democratization and public law often see the extensive involvement of the judiciary in the political arena as undesirable. They recognize that some level of judicialization of politics is necessary for the functioning of the modern state and for the creation of democratic accountability, yet they warn that over-judicialization of politics can be a destabilizing factor. They warn that reliance on the courts in settling controversial political disputes undermines the regime's cohesion by discouraging political compromises that are part of the political process. These arguments, however, generally draw their conclusions based on cases of purely authoritarian or democratic regimes. In view of the evidence presented in this article, it is necessary to modify some of these arguments.

Iran and Turkey represent political structures that combine authoritarian and democratic practices and institutions. In these countries, sovereignty is divided between elected executives and unelected ones who act as guardians of the regime. High levels of tension and conflict are inherent in such systems. Divided sovereignty is based on a system of "contending authorities" in which the democratic elements of the system encourage change while its non-democratic features try to limit the ideological and social aspects 
of that change. ${ }^{83}$ The resulting social conflict encourages the involvement of the courts. This judicialization of politics, however, is not necessarily destabilizing. In fact, judicialization is an integral part of the mechanism used by the guardians to maintain the overall division of sovereignty. The courts are empowered to decide controversial political issues to limit the influence of the popularly elected institutions and to preserve the privileges of the guardians.

Relying on the judiciary to limit the influence of elected officials and to remove those who are unacceptable has several advantages. First, in countries such as Iran and Turkey, courts are formally designed to serve as checks on the powers of elected officials, while they have little or no control over the guardians. Both the Turkish military and the Iranian Supreme Leader are exempt from the jurisdiction of civilian courts. Some have even gone as far as to suggest that the Supreme Leader is "infallible." Second, the courts are likely to be sympathetic to the views of the guardians. In Iran, the Supreme Leader has direct control over the judiciary and can guarantee a favorable outcome through the judicial process. Even in Turkey, where the military has no direct control over the judiciary, the military is likely to find the courts more sympathetic than elected political institutions such as legislatures and city councils. Unlike legislative bodies, courts are not directly accountable to voters, and at least in theory, they are not influenced by public opinion. Furthermore, the "merit-based" promotion and selection process used in Turkey produces a judicial system that, at least at its upper levels, where most politically sensitive cases are likely to end up, is sympathetic to the views of the guardians. ${ }^{84}$

Third, the guardians hope that by turning to the courts they can enhance the legitimacy of their actions while creating a dilemma for the elected executive. The rule of law, even undemocratic law, is at the heart of democracy. Hence, the guardian's attempt to enforce the law is presented as legitimate and democratic, while the elected head's resistance becomes illegitimate and undemocratic. Fourth, turning to courts is an attempt to bring "finality" to the discussion without a direct confrontation between the guardians and the elected executive. As a former president of the Turkish Constitutional Court noted, one purpose of going to court is to "put a stop to complaints [and] debates, ... and to put an end to controversies." ${ }^{85}$

These two last functions, however, are dependent on the public's perception of the impartiality of courts as arbiters and the "justness" of their decisions. Although courts are not expected to consider public sentiments in making decisions, their power lies in the acceptance of their decisions by the people. This is particularly important in politically sensitive cases where the real battle is for the hearts and minds of the public. As the Iranian commentator Akbar Ganji, himself a victim of the crackdown on reformers, notes, " [I]n political crimes the court decision is not binding, if it is not accepted as binding by the people." 86 It is here that the failure of the Iranian and Turkish judiciaries is most evident. The public reaction to the convictions of Karbaschi and Erdoğan, and to similar judicial decisions, suggests that the judiciary's active involvement in political controversies has eroded its image as a neutral arbiter among the public. Karbaschi and Erdoğan are not unique. A similar disregard for the courts' decisions can be seen in the closure of political parties and politically disagreeable publications. Turkey's two leading Islamist political parties, the Justice and Development Party and the Felicity Party (Saadet Partisi), are successors to the banned Fazilet Party. Fazilet itself had replaced the banned Refah Party (closed by the Constitutional Court in 1998), which itself had replaced the banned 
National Salvation Party (closed after the 1980 military coup), which had replaced the National Order Party (closed by the Constitutional Court in 1971). ${ }^{87}$ Similarly, banned Iranian publications have reappeared under different names with seemingly no damage to their reputation. When the press court closed the daily Jame'eh, it reappeared as Tus. When Tus was shut down, Neshat replaced it. Neshat's closure was followed by the publication of 'Asr-e Azadegan as the new reformist newspaper.

Surprisingly, however, the failure of the courts to produce popularly acceptable decisions contributes to the continued division of sovereignty between elected and unelected institutions. Linz, Arturo Valenzuela, and others are correct in pointing out that judicialization of politics points to the breakdown of cohesion in the ruling bloc and that it fans political and social tensions. In countries where elected and unelected executives have to cohabit, however, a high level of tension is needed for the survival of the system. The disregard shown for judicial decisions tends to justify the continued vigilance of the unelected head. Relations between the two heads of the executive in such systems are perhaps best described by Turkey's former President Süleyman Demirel, who, when asked in 1998 for his thoughts on a looming crisis between Prime Minister Mesut Y1lmaz and the military high command, replied,

In an English zoo there was an experiment to have wolves and lambs live together in one cage. Someone asked the director if the experiment was working. The director replied, yes, but sometimes we have to replace the lambs. ${ }^{88}$

Without a high level of tension to keep the sides at a safe distance from each other, the cohabitation of the wolf and the lamb is not likely. In political systems based on divided sovereignty, the tensions created by the reliance on "neutral" forces to address essentially political issues are necessary for the maintenance of the regime.

\section{NOTES}

Author's note: Earlier versions of this paper were presented at the annual meetings of the American Political Science Association (Atlanta, 1999) and the Middle East Studies Association (Washington, D.C., 1999). I am indebted to the following individuals for their comments and suggestions: Faith Childress, Ümit Cizre, Todd Fogelsong, Ömer Faruk Gençkaya, Metin Heper, Ahmet Içduygu, Fuat Keyman, Susan Olson, Ergun Özbudun, and the editor and annonymous reviewers of IJMES. I also thank my research assistant Murat Çemrek.

${ }^{1}$ Larry Diamond, Developing Democracy: Toward Consolidation (Baltimore: Johns Hopkins University Press, 1999), 111.

${ }^{2}$ Juan Linz, The Breakdown of Democratic Regimes: Crisis, Breakdown, and Reequilibrium (Baltimore: Johns Hopkins University Press, 1978); Arturo Valenzuela, The Breakdown of Democratic Regimes: Chile (Baltimore: Johns Hopkins University Press, 1978).

${ }^{3}$ Linz, Breakdown of Democratic Regimes, 69.

${ }^{4}$ Valenzuela, Breakdown of Democratic Regimes: Chile, $80-81$.

${ }^{5}$ C. Neal Tate, "Why the Expansion of Judicial Power," in The Global Expansion of Judicial Power, ed. C. Neal Tate and Torbjorn Vallinder (New York: New York University Press, 1995), 27-37. In an earlier article, Tate argued that authoritarian regimes, too, might find an independent judiciary beneficiary: see C. Neal Tate, "Courts and Crisis Regimes: A Theory Sketch with Asian Case Studies," Political Research Quarterly (1992): 311-38.

${ }^{6}$ Nathan Brown, The Rule of Law in the Arab Middle East: Courts in Egypt and the Gulf (Cambridge: Cambridge University Press, 1997), 241.

${ }^{7}$ In Chile, for example, while General Pinochet did not interfere with the independence of the judiciary, the Chilean Supreme Court found the policies of the authoritarian regime more agreeable than those of its 
democratically elected predecessor. Before leaving office, General Pinochet packed the Supreme Court with his supporters: see Jorge Correa Sutil, "The Judiciary and the Political System in Chile: The Dilemmas of Judicial Independence during the Transition to Democracy," in Transition to Democracy in Latin America: The Role of the Judiciary, ed. Irwin P. Stotzky (Boulder, Colo.: Westview Press, 1993), 89-106.

${ }^{8}$ Tate, "Courts and Crisis Regimes."

${ }^{9}$ In the Philippines, for example, the number of politically significant cases decided by the Supreme Court rose during both the crisis of the democratic regime that brought Ferdinand Marcos to power and during the demise of his dictatorship: see C. Neal Tate, "Courts and the Breakdown and Recreation of Philippines Democracy: Evidence from the Supreme Court's Agenda,” International Social Science Journal (1997): 279 91.

${ }^{10}$ Stephen D. Krasner, “A World Court That Could Backfire,” New York Times, 15 January 2001.

${ }^{11}$ Terry Lynn Karl, "Dilemmas of Democratization in Latin America," in Comparative Political Dynamics: Global Research Perspectives, ed. Dankwart A. Rustow and Kenneth O. Erickson (New York: HarperCollins, 1991), 180.

${ }^{12}$ J. Samuel Fitch, The Armed Forces and Democracy in Latin America (Baltimore: Johns Hopkins University Press, 1998), 38-40.

${ }^{13}$ Daniel Brumberg, Reinventing Khomeini: The Struggle for Reform in Iran (Chicago: University of Chicago Press, 2001), 33-34.

${ }^{14}$ Stephan Haggard and Robert R. Kaufman, The Political Economy of Democratic Transitions (Princeton, N.J.: Princeton University Press, 1995), 121.

${ }^{15}$ Both General Pinochet in Chile and General Evren in Turkey used this tactic.

${ }^{16}$ Brumberg, Reinventing Khomeini, 34.

${ }^{17}$ Asghar Schirazi, The Constitution of Iran: Politics and the State in the Islamic Republic, trans. John O'Kane (London: I. B. Tauris, 1997).

${ }^{18}$ Ibid., 52.

${ }^{19}$ This typology is based on Juan Linz and Alfred Stepan, Problems of Democratic Transition and Consolidation: Southern Europe, South America, and Post-Communist Europe (Baltimore: John Hopkins University Press, 1996), chap. 3.

${ }^{20} \mathrm{H}$. E. Chehabi, "The Political Regime of the Islamic Republic of Iran in Comparative Perspective," Government and Opposition 36 (2001): 48-70.

${ }^{21}$ On parliamentary politics in Iran, see Bahman Baktiari, Parliamentary Politics in Revolutionary Iran (Gainesville.: University of Florida Press, 1996).

${ }^{22}$ Chehabi, "Political Regime," 65.

${ }^{23}$ On the Iranian constitution and the system that it has created, see Schirazi, Constitution of Iran, and Wilfried Buchta, Who Rules Iran? The Structure of Power in the Islamic Republic (Washington, D.C.: Washington Institute for Near East Policy, 2000).

${ }^{24}$ The Council of National Security (Milli Güvenlik Konseyi) consisted of the military generals who had led the coup and is different from the National Security Council (Milli Güvenlik Kurulu).

${ }^{25}$ Ergun Özbudun, “Turkey: Crises, Interruptions, and Reequilibriums," in Politics in Developing Countries: Comparing Experiences with Democracy, 2nd ed., ed. Larry Diamond, Juan J. Linz, and Seymour Martin Lipset (Boulder, Colo.: Lynne Rienner, 1995), 238.

${ }^{26}$ Provisional Article 1 of the constitution specified that, upon the proclamation of the constitution, "the Chairman of the Council of National Security and Head of State [General Evren], shall assume the title of the President of the Republic and shall exercise the constitutional functions and powers of the President for a period of seven years."

${ }^{27}$ Özbudun, "Turkey."

${ }^{28}$ Ümit Cizre Sakallioğlu, "The Anatomy of the Turkish Military's Political Autonomy," Comparative Politics (1997): 158. One can also argue that, given the extensive powers of the presidency, what has been established is a triple-headed executive system. On the powers of the Turkish presidency, see Ergun Özbudun, "The Status of the President of the Republic under the Turkish Constitution of 1982: Presidentialism or Parliamentarism?" in State, Democracy and the Military: Turkey in the 1980s, ed. Metin Heper and Ahmet Evin (Berlin: Walter de Gruyter, 1988), 37-45.

${ }^{29}$ The participation of the NSC's secretary-general, always an active-duty military officer, in the council's deliberations means that the armed forces enjoy numerical superiority on the council. In October 2001, the number of civilians on the council was increased. By itself, however, this change is unlikely to decrease the 
military's influence. As the military chief of general staff has noted, the military does not object to introducing "even 100 civilians to the Security Council if that is the wish of the [European Union]," because the NSC's decisions are made "not by majority of votes, but by consensus:" see Eric Rouleau, "Turkey's Modern Pashas," Le Monde diplomatique, English ed., 4 September 2000.

${ }^{30}$ The wording was changed in October 2001 to emphasis the advisory nature of the NSC.

${ }^{31}$ Ömer Faruk Gençkaya, "The Impact of Organizational Attributes on Legislative Performance: A Structural-Functional Analysis of the Grand National Assembly of Turkey, 1983-1987” (Ph.D. diss., Boğazici University, Istanbul, 1990), 45.

${ }^{32}$ Ahmet Evin, "Demilitarization and Civilianization of the Regime," in Politics in the Third Turkish Republic, ed. Metin Heper and Ahmet Evin (Boulder, Colo.: Westview Press, 1994), 25; see also Özbudun, Contemporary Turkish Politics, chap. 5.

${ }^{33}$ Sakallioğlu, "Anatomy," 158.

${ }^{34}$ William Hale, Turkish Politics and the Military (London: Routledge, 1994); Metin Heper and Aylin Güney, "The Military and Democracy in the Third Turkish Republic," Armed Forces and Society (1996): 619-42; Metin Heper and Aylin Güney, "The Military, Political Islam, and Democracy in Turkey," Armed Forces and Society (2000): 635-57; Ben Lombardi, “Turkey: The Return of Reluctant Generals?” Political Science Quarterly 112 (1997): 191-215.

${ }^{35}$ One of the complaints against former Prime Minister Erbakan was that, although he had agreed to the decisions reached at the NSC meeting on 28 February 1997, he had failed to enact them into law.

${ }^{36}$ Strictly speaking, the Supreme Leader is an elected official. An elected assembly of religious experts, the Majles-e Khobregan, selects him for life. The indirect manner of his election, the permanency of his position, his lack of accountability to elected institutions and the population at large, the limitations put on membership in the Assembly of Experts, and his claim to quasi-infallibility, however, have meant that in practice he is an unelected official.

${ }^{37}$ These boards have extensive policy-making powers and do not limit themselves to a supervisory role.

${ }^{38}$ Both Turkish jurists and international observers have criticized the presence of the minister of justice and the under-secretary of the Ministry of Justice on the Supreme Council of Judges and Public Prosecutors as a threat to the independence of the judiciary: see Lawyers Committee for Human Rights and Crowley Program in International Human Rights, Obstacles to Reform: Exceptional Courts, Police Impunity and Persecution of Human Rights Defenders in Turkey (New York: Lawyers Committee for Human Rights and Crowley Program in International Human Rights, 1999).

${ }^{39}$ Ömer Faruk Gençkaya, "The Turkish Constitutional Court and the Dissolution of Political Parties: Comparative Perspectives," in Suna Kili'ye Armağan: cumhuriyete adanan bir yaşam (Istanbul, 1998), 16584.

${ }^{40}$ Erhard Blankenburg, "Changes in Political Regimes and the Continuity of the Rule of Law in Germany," in Law and Politics in Comparative Perspective, ed. Jacob Herbert et al. (New Haven, Conn.: Yale University Press, 1996), 265.

${ }^{41}$ Some of the parties were closed for administrative reasons, such as the failure to file the appropriate forms. Others, however, were closed for ideological reasons. Of these, the most important were pro-Kurdish political parties such as the Democratic Party and the People's Party. In January 1998, the court closed the Islamist Refah Party, which at the time was the single largest political party in Parliament. Refah's successor, the Fazilet Party, was closed in June 2001. On party closures in Turkey, see Gençkaya, "Turkish Constitutional Court."

${ }^{42}$ Yekta Güngör Özden, “Opening Speech by Yekta Güngör Özden, President of the Turkish Constitutional Court," Constitutional Jurisdiction 9 (1993): 15.

${ }^{43}$ Mehmet Turhan, The Constitutional Court of Turkey (Ankara: Constitutional Court, 1991), 4-5.

${ }^{44}$ The European Court of Human Rights found the presence of the military judge to be in violation of the defendant's right to trial before a fair and impartial tribunal: European Court of Human Rights in Incal $v$ Turkey (EHCR 41/1997/825/1031), 9 June 1998. In June 1999, in anticipation of criticism from the European Court concerning the trial of the Kurdish separatist leader Abdullah Ocalan, Parliament amended the constitution to replace the military judges serving on SSCs with civilian judges.

${ }^{45}$ Özden, "Opening Speech," 9, 22.

${ }^{46}$ Turkish News, 17 February 2001. The chief prosecutor is responsible for filing cases against political parties.

${ }^{47}$ Eric Rouleau, "Iran: An Economy in Need of Reform,” Middle East Economic Survey 42 (1999). 


\section{Hootan Shambayati}

${ }^{48}$ On the role of the press in Khatami's victory and the judiciary's attack on the press, see Zarir Merat, "Pushing Back the Limits of the Possible: The Press in Iran," Middle East Report 212 (1999), 32-35; Ramin Karimian and Sha'banali Bahrampour, "Iranian Press Update," Middle East Report 212 (1999), 38-39.

${ }^{49}$ Fariba Adelkhah, Being Modern in Iran, trans. Jonathan Derrick (New York: Columbia University Press, 2000), 23.

${ }^{50}$ Jahangir Amuzegar, “Khatami’s Iran, One Year Later," Middle East Policy 6 (1998): 76-93; Shaul Bakhash, "Iran's Remarkable Election," Journal of Democracy (1998): 80-94; Stephen C. Fairbanks, "Theocracy versus Democracy: Iran Considers Political Parties," Middle East Journal (1998): 17-31; Farhang Rajaee, "A Thermidor of 'Islamic Yuppies'? Conflict and Compromise in Iran's Politics," Middle East Journal (1999): 217-31.

${ }^{51}$ Rajaee, “'Islamic Yuppies'?” 226.

${ }^{52}$ Ibid.

${ }^{53}$ The charges against Karbaschi were partially based on the "confessions" of arrested municipal officials, some of whom filed a lawsuit against the security officials for allegedly using excessive force and torture in obtaining their testimonies. That trail did result in the conviction of some of the security officers involved.

${ }^{54}$ Kar va Kargar reported that a deal had been struck according to which Karbaschi would be put on trial and found guilty and would receive a reduced sentence but would be permanently discharged from government service. The paper also reported that Ayatollah Yazdi would not seek reappointment as the head of the judiciary: (“Iran: Tehran Paper Predicts Yazdi’s, Tehran Mayor's Replacement," IRNA, 22 April 1998, FBIS-NES-98-112, 22 April 1998. In June 1999, Ayatollah Yazdi announced that he would not ask for the renewal of his term.

${ }^{55}$ The trial was held in Public Court (Dadgah-e 'am), where the judge also acts as the prosecutor. On Iran's judicial system, see Azadeh Niknam, "The Islamization of Law in Iran: A Time of Disenchantment," Middle East Report 212 (1999), 17-21.

${ }^{56}$ See Karbaschi, Muhakimih va Defa' (Tehran: Farhang va Andisheh, 1998). This line of defense, as Adelkhah points out, is not uncommon in Iran and fits well within the culture of javanmardi: see Adelkhah, Being Modern in Iran.

${ }^{57}$ At least one newspaper publisher, Abdullah Nouri, was charged with the crime of agitating public opinion against the judiciary by publishing a reader's letter criticizing the court verdict against Karbaschi: see Abdullah Nouri, Shukran-i islah: Defa'iyat-i Abdullah Nouri (Hemlock for Advocate of Reform: The Complete Text of Abdullah Nouri's Defense at the Special Clerical Court) (Tehran: Tarh-e No, 1999), 102-106.

58 “Khatami Regrets Iran Deprived of Karbaschi's Services," IRNA, 8 May 1999, FBIS-NES-1999-0508, 8 May 1999.

59“Why Regrets for Karbaschi?” Tehran Times, 10 May 1999, FBIS-NES-1999-0510, 10 May 1999.

${ }^{60}$ Bizhan Moqaddam, "Iran: Political Groupings, Law Abidingness Viewed," Resalat, 26 July 1998, FBISNES-98-239, 27 August 1998.

${ }^{61} \mathrm{He}$ will not serve any additional prison time; nor will he pay the 1,600 million rial fine. The ban on holding public office remains intact: Jonathan Lyons, "Teheran Ex-Mayor Freed, Returns to Politics," Reuters, 25 January 2000, available from: http://dailynews.yahoo.com/h/nm/20000125/wl/iran_mayor_2.html. Ironically, the pardon hurt Karbaschi's reputation, and the reformers criticized him for accepting the pardon: see Morteza Mardiha, "Marg-e Qahraman" (The Death of the Hero), reprinted in Akbar Ganji, 'Alijenab-i Surkhposh va 'alijenab-i khakestari: Asibshenasi gozara beh doulat-i demokratik-i tos'ehgara (The Red Eminence and the Gray Eminences: Pathology of Transition to the Developmental Democratic State) (Tehran: Tarh-e No, 2000), 250-52. Mardiha's column originally appeared in 'Asr-e Azadegan, 31 January 2000.

${ }^{62}$ Sakallioğlu, "Anatomy," 158.

${ }^{63}$ The military accused the government of being soft on Islamic fundamentalism. Its recommendations to combat the threat of fundamentalism were adopted by the NSC on 28 February 1997. However, the military continued to criticize the government for not implementing the recommendations.

${ }^{64}$ The Constitutional Court closed the Fazilet Party in June 2001.

${ }^{65}$ The court verdict noted that the case against Erdoğan was related to the activities of the Refah Party in office.

${ }^{66}$ The National Salvation Party and all other political parties were closed after the 1980 military coup.

${ }^{67}$ Ugur Akinci, “The Welfare Party's Municipal Track Record: Evaluating Islamist Municipal Activism in Turkey," Middle East Journal 53 (1999): 75-94; Metin Heper, "Islam and Democracy in Turkey: Toward a Reconciliation?” Middle East Journal 51 (1997): 32-45; Sabri Sayari, “Turkey's Islamist Challenge” Middle East Quarterly (1996): 35-43; Jenny B. White, "Pragmatists or Ideologues? Turkey's Welfare Party in Power," 
Current History (1997): 25-30; Hakan Yavuz, "Political Islam and the Welfare Party in Turkey," Comparative Politics 30 (1997): 63-82.

${ }^{68}$ His legal team has published the documents relating to the case: see Faik Işik, ed., Recep Tayyip Erdoğan Davast (Recep Tayyip Erdoğan's Trial) (Istanbul, 1998).

${ }^{69}$ Anatolia Agency, 4 June and 23 September 1998, FBIS-WEU-98-266.

${ }^{70}$ Anatolia Agency, 29 September 1998; U.S. Department of State. "Turkey: Country Report on Human Rights Practices for 1998," Washington, D.C., 1999.

${ }^{71}$ Metin Heper, ed., Local Government in Turkey: Governing Greater Istanbul (London: Routledge, 1989).

${ }^{72}$ Erdoğan made this claim during his speech in Siirt.

${ }^{73}$ Karbaschi, Muhakimih va Defa', 107-108.

${ }^{74}$ Ibid., 216-17, 321-23.

${ }^{75}$ White, "Pragmatists or Ideologues?" 26.

${ }^{76}$ Kaveh Ehsani, "Municipal Matters," Middle East Report 212 (1999): 22-27.

77 “Rationality Should Rule in Karbaschi’s Trial," Tehran Times, 11 June 1998, FBIS-NES-98-167, 16 June 1998.

78،Remote Control," Keyhan, 8 May 1999, FBIS-NES-1999-0509, 8 May 1999.

${ }^{79}$ The press court shut down Hammihan on 16 May 2001.

${ }^{80}$ Former President Hashemi-Rafsanjani had differences with Ayatollah Khamenei concerning the modernization of the economy and the relaxation of some social restrictions.

${ }^{81}$ Mardiha, "Marg-e Qahraman,” 250-51.

${ }^{82}$ On Karbaschi, see Adelkhah, Being Modern in Iran, and Rajaee “'Islamic Yuppies'?” On Erdoğan, see Metin Heper and Şoleh Toktaş, "Islam, Modernity, and Democracy in Contemporary Turkey: The Case of Recep Tayyip Erdoğan,” The Muslim World 93 (2003): 157-85.

${ }^{83}$ Brumberg, Reinventing Khomeini, 5.

${ }^{84}$ Promotion of Turkish judges is partially based on the review of their decisions by more senior judges.

${ }^{85}$ Özden, “Opening Speech," 16.

${ }^{86}$ Akbar Ganji, "Tanaquz dar Guftar, bi 'adalati dar raftar" (Contradiction in Talk, Injustice in Action), in Ganji, Red Eminence, 80.

${ }^{87}$ Pro-Kurdish political parties have followed a similar pattern. Since 1993, the Constitutional Court has closed two pro-Kurdish political parties; a case against the third is pending: See Nicole F. Watts, "Allies and Enemies: Pro-Kurdish Parties in Turkish Politics, 1990-94," International Journal of Middle East Studies 31 (1999): 631-56.

${ }^{88}$ Fikret Bila, "Baba`dan 'kuzu' benzetmesi," Milliyet, Internet ed., 23 March 1998, available from: http://www.milliyet.com.tr/1998/03/22/index.html. 